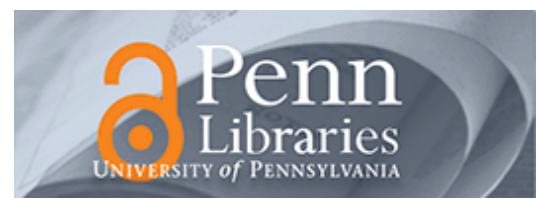

University of Pennsylvania

ScholarlyCommons

\title{
On not Taking Language Inequality for Granted: Hymesian Traces in Ethnographic Monitoring of South Africa's Multilingual Language Policy
}

Nancy H. Hornberger

University of Pennsylvania, nancyh@gse.upenn.edu

Follow this and additional works at: https://repository.upenn.edu/gse_pubs

Part of the African Studies Commons, Anthropological Linguistics and Sociolinguistics Commons, Applied Linguistics Commons, Bilingual, Multilingual, and Multicultural Education Commons, Education Policy Commons, International and Comparative Education Commons, Linguistic Anthropology Commons, Scholarship of Teaching and Learning Commons, and the Social and Cultural Anthropology Commons

\section{Recommended Citation}

Hornberger, N. H. (2014). On not Taking Language Inequality for Granted: Hymesian Traces in Ethnographic Monitoring of South Africa's Multilingual Language Policy. Multilingua, 33 (5-6), 623-645. http://dx.doi.org/10.1515/multi-2014-0031

This paper is posted at ScholarlyCommons. https://repository.upenn.edu/gse_pubs/308

For more information, please contact repository@pobox.upenn.edu. 


\title{
On not Taking Language Inequality for Granted: Hymesian Traces in Ethnographic Monitoring of South Africa's Multilingual Language Policy
}

\begin{abstract}
South African higher education is at a critical juncture in the implementation of South Africa's multilingual language policy promoting institutional status for nine African languages, English, and Afrikaans. South African scholars, not content merely to comment from the sidelines on the policy, its promise, and challenges, have also engaged in implementation efforts. This article explores two such initiatives, both focusing on the use of African languages in higher education institutions where English is already established as the medium of instruction, and both undertaken with explicit goals of righting South Africa's longstanding social injustices. I collaborated with colleagues at the University of Limpopo and the University of KwaZulu-Natal to assess current implementation and identify next steps and strategies for achieving truly multilingual teaching, learning, and research at their institutions. Taking up Hymes' (1980) call for ethnographic monitoring of bilingual education, I sought in each case to jointly describe and analyze current communicative conduct, uncover emergent patterns and meanings in program implementation, and evaluate program and policy in terms of social meanings. I argue that ethnographic monitoring in education offers one means toward not taking language inequality for granted.
\end{abstract}

\section{Keywords}

biliteracy, ethnography, language policy, isiZulu, bilingual higher education, seSotho sa Leboa

\section{Disciplines}

African Studies | Anthropological Linguistics and Sociolinguistics | Applied Linguistics | Bilingual, Multilingual, and Multicultural Education | Education | Education Policy | Higher Education | International and Comparative Education | Linguistic Anthropology | Scholarship of Teaching and Learning | Social and Cultural Anthropology 


\title{
On not taking language inequality for granted:Hymesian traces in ethnographic monitoring of South Africa's multilingual language policy
}

\author{
Nancy H. Hornberger \\ University of Pennsylvania \\ nancyh@upenn.edu
}

\section{Abstract}

South African higher education is at a critical juncture in the implementation of South Africa's multilingual language policy promoting institutional status for nine African languages, English, and Afrikaans. South African scholars, not content merely to comment from the sidelines on the policy, its promise, and challenges, have also engaged in implementation efforts. This paper explores two such initiatives, both focusing on the use of African languages in higher education institutions where English is already established as the medium of instruction, and both undertaken with explicit goals of righting South Africa's longstanding social injustices. I collaborated with colleagues at the University of Limpopo and the University of KwaZulu-Natal to assess current implementation and identify next steps and strategies for achieving truly multilingual teaching, learning, and research at their institutions. Taking up Hymes' (1980) call for ethnographic monitoring of bilingual education, I sought in each case to jointly describe and analyze current communicative conduct, uncover emergent patterns and meanings in program implementation, and evaluate program and policy in terms of social meanings. I argue that ethnographic monitoring in education offers one means toward not taking language inequality for granted. 
2 Nancy H. Hornberger

Key words: biliteracy, ethnography, language policy, isiZulu, bilingual higher education, seSotho sa Leboa

\section{Introduction}

South African higher education is at a critical juncture in implementation of South Africa's multilingual language policy promoting institutional status for nine African languages, English, and Afrikaans (van der Walt 2004). Drawing on almost two decades of periodic short-term ethnographic work in South Africa, I recently engaged in participant-observation and dialogue with faculty, administrators, undergraduate, and post-graduate students in two institutions of higher education there, at their invitation, to jointly assess current implementation and identify next steps and strategies for achieving truly multilingual teaching, learning, and research. Concurring with Hymes that ethnographic monitoring of programs can be of great importance with regard to educational success and political consequences, I undertook my work from a collaborative ethnographic stance, in which the participants and I jointly sought to describe and analyze current communicative conduct, uncover emergent patterns and meanings in program implementation, and evaluate the program and policy in terms of social meanings (Hymes 1980).

In this article, I undertake to explore two related sets of questions emerging from these experiences: firstly, how does an ethnographer consult internationally on language education policy? Can this effort be understood as ethnography, in the sense of long-term participant observation yielding an emic and holistic account of a cultural situation or topic? Does ethnographic monitoring offer an option for doing ethnography on the shortterm basis a consultancy demands? Secondly, how is post-apartheid South Africa's 
multilingual language policy affecting Black African learners' academic opportunities? Can South Africa's multilingual language policy move beyond a seemingly one step forward, two steps back pattern? Can ethnographic monitoring yield some answers toward that end? In what follows, I first provide a very brief background on South Africa's post-apartheid multilingual language policy, on Hymes' proposal for ethnographic monitoring, and on the methodological toolkit, conceptual repertoire, and knowledge of the South African context I brought to these ethnographic monitoring experiences. The body of the paper then takes up two very different cases, at the University of Limpopo in 2008 and the University of KwaZulu-Natal in 2010, in search of tentative answers to the questions. For each case, I briefly introduce the context and the tasks I undertook, followed by an abbreviated account of what emerged through ethnographic monitoring. The article concludes with a look back at the opening questions as to the reach of ethnographic monitoring and of South Africa's multilingual language policy. To realize the promise of the policy, there is a need for multilingual education alternatives that take and build on Black African learners' home languages in additive rather than subtractive ways; such efforts require constant and well-documented persistence. Ethnographic monitoring can play a role in this enduring endeavor.

\section{South Africa's multilingual language policy (MLP)}

Post-apartheid South Africa's Constitution of 1996 embraces language as a basic human right and multilingualism as a national resource, raising nine major African languages to national official status alongside English and Afrikaans — specifically, isiNdebele, Northern seSotho, Southern seSotho, SiSwati, xiTsonga, seTswane, tshiVenda, isiXhosa 
and isiZulu. Along with the dismantling of the apartheid educational system, this has led to the burgeoning of multilingual, multicultural student populations in schools, classrooms, and universities nationwide.

While the federal government has invested institutional resources to implement the policy, including a national language planning board (PANSALB), and individual language planning bodies for each official language (PANSALB 2001; Perry 2004), it has become evident that there is huge variation in policy implementation across provinces, with some provinces such as the Western Cape being very proactive and others less so (Plüddemann 2013). The policy, its promise, and its challenges have drawn considerable scholarly attention from within and outside South Africa (Bloch and Alexander 2003; Chick 2003; Granville et al. 1998; Heugh et al. 1995; Kamwangamalu 1997; Webb 2002; Wildsmith-Cromarty 2009). The policy and its implementation in education in particular are not without controversy, with scholars observing, for example, that the national educational policy contradicts the language policy in significant ways (Heugh 2003); and others documenting and critiquing the rush to English-medium schools by African parents (e.g. Alexander 2000; Banda 2000; Probyn 2001; Ridge 2004).

Not content merely to comment from the sidelines, numerous eminent South African scholars have also engaged directly in implementation efforts at all levels of the education system. While complex issues continue to be identified and addressed in primary and secondary education, there has also been increased attention in recent years to policy implementation at the university level (Ndimande 2004; van der Walt 2004; van der Walt and Brink 2005), as exemplified by the institutional programs I discuss below. The cases I explore here are higher education initiatives largely or entirely undertaken by 
scholars, focusing explicitly on the use of African languages in institutions where English is already well established as the medium of instruction, and with explicit goals of righting South Africa's longstanding social injustices.

\section{Hymes' ethnographic monitoring}

Writing three decades ago with respect to U.S. bilingual education policy and programs, Hymes posits that ethnographic monitoring of programs can be of great importance with regard to documenting and furthering both the educational success and political consequences of the programs. He discusses three overriding purposes and activities of ethnographic monitoring, which I summarize as: firstly, description of current communicative conduct in programs; secondly, analysis of emergent patterns and meanings in program implementation; and thirdly, evaluation of the program and policy in terms of social meanings, specifically with regard to countering educational inequities and advancing social justice.

Regarding the first, descriptive, purpose, Hymes proposes that one has to recognize and interpret accurately students' and teachers' communicative conduct "in order to know what one wishes to change" (Hymes 1980: 107); and he suggests this encompasses both rules of language and rules of language use, offering as examples practices around language mixing and enforcement of linguistic norms (Hymes 1980). Consistent with his foundational writings on the ethnography of communication and communicative competence (Hymes 1968, 1972, 1974), he further argues that it is the functions of language that are fundamental, while language forms are primarily instrumental. Thus, one has to discover not just "what varieties of language are in use, when and where and 
by whom, what features of language vary according to what parameters" but also "what varieties of language, features of language are being used for and to what effect" (Hymes 1980: 113; emphasis in the original).

Moving to the more analytical and evaluative second and third purposes of ethnographic monitoring, Hymes urges ethnographic monitors to ask what is said about the program and about those who succeed or do less well, and what is presupposed in what is said. Examining emergent patterns and meanings in program implementation, one might uncover, for example, that a student who does poorly is considered stupid, or that students from a particular class or neighborhood or kind of family consistently do well, while others consistently do poorly (Hymes 1980: 114).

Once these patterns and meanings are uncovered in the ongoing operation of programs, the third purpose of ethnographic monitoring turns the lens to outcomes evaluating the effects and consequences of the program and of the policy as a whole. Here, both educational success as measured by student outcomes and political consequences of the program in terms of advancing equity are of interest. Observing that schools have implicitly functioned to define some people as inferior and that they do so on the "seemingly neutral ground of language", whereas "bilingual education challenges the very fabric of schooling insofar as it adheres to the goal of overcoming linguistic inequality by changing what happens in schools themselves" (Hymes 1980: 110-111), Hymes foretold that in a few years' time the charge would likely be made that U.S. bilingual education had failed, with arguments being formulated along lines of both educational success and political consequences. 
The clairvoyance and generalizability of Hymes' observations are startling; what he wrote in the late 1970s in connection with critiques of U.S. bilingual education is equally relevant today for multilingual language policy in South Africa (and for language education policy in many other parts of the world). But he does not stop there. He offers a remedy - ethnographic monitoring of programs, he says, can be of great importance in countering such criticisms (Hymes 1980). In prescient anticipation of what would come to be an intractable problem in bilingual education program evaluation, he writes: "An evaluation in terms of gross numbers can only guess at what produced the numbers, and indeed, can only guess as to whether its numbers were obtained with measures appropriate to what is being evaluated" (Hymes 1980: 115); but he goes on to suggest that "the ethnographic approach can go beyond tests and surveys to document and interpret the social meaning of success and failure to bilingual education" (Hymes 1980: 117). Via ethnography, the "circumstances and characteristics of successful results can be documented in ways that carry conviction" (Hymes 1980: 116).

What is more, Hymes suggests that ethnography can provide illumination as to the politics underlying arguments against bilingual education: "To argue that bilingualism is divisive is really to argue that it makes visible what one had preferred to ignore, an unequal distribution of rights and benefits. It is common to call 'political' and 'divisive' the raising of an issue that one had been able to ignore, and to ignore the political and oppressive implications of ignoring it" (Hymes 1980: 117). Ethnographic monitoring, though, makes it impossible to ignore the unequal distribution of rights and benefits that is truly divisive in multilingual contexts, and to which multilingualism and multilingual education are creative responses (Haugen 1973). The ongoing challenge for ethnographic 
monitors is to bring that ethnographic awareness forcefully to the attention of politicians and policymakers.

Finally, Hymes suggests that ethnographic monitoring need not and should not be the isolated task of the ethnographer, but rather can and should be undertaken in cooperation with program participants, who have the firmest understanding of the program's operation, its challenges, and successes. Van der Aa and Blommaert review Hymes et al.'s 1981 report on a three-year ethnographic monitoring project in Philadelphia's public schools, emphasizing that Hymes "proposes a continuing mutual inquiry, not just 'reporting back,' because intensive and genuine co-operation is at the heart of ethnographic monitoring" (van der Aa and Blommaert 2011: 324). They emphasize the report's insistence on making "findings the possession of the school people who have contributed to their discovery" (Hymes et al. 1981: 6); and they underline, as did Hymes, that this is not just a matter of courtesy, but of good research method (van der Aa and Blommaert 2011; Hymes et al. 1981).

Something that works very much in the ethnographer's favor for a collaborative ethnographic monitoring effort is the fact that ethnography is, in one sense, very accessible. Hymes saw the skills of the ethnographer as an extension of what humans normally do to "learn the meanings, norms, and patterns of a way of life . . . The fact that good ethnography entails trust and confidence, that it requires some narrative accounting, and that it is an extension of a universal form of personal knowledge, make me think that ethnography is peculiarly appropriate to a democratic society" (Hymes 1980: 98-99).

At the same time, ethnography is not simply a fieldwork method, but a methodological and conceptual paradigm. Blommaert has written eloquently about this, 
highlighting first that ethnography has always been about theory and not just method, that it "contains ontologies, methodologies, and epistemologies" (Blommaert 2009: 262); and second that Hymes' work stands out for rescuing this history and advancing ethnography as descriptive theory. In differentiating between a linguistic notion of language and an ethnographic notion of speech, Hymes offers a theoretical perspective on language and communication that is essentially critical and counterhegemonic, in search of a complexifying rather than simplifying description and analysis of social reality (Blommaert 2009: 267).

\section{An ethnographic toolkit for international consulting}

In the South African cases I explore here, the nature of my task readily lent itself to collaboration. At both institutions, I was there at the invitation of colleagues and was expected to meet with a broad range of participants; to define my work as ethnographic and collaborative suited both their goals and mine. They are the experts, and I am the outside facilitator, who brings experience in language education policy in multilingual contexts. As will become evident in the accounts below and in their publications cited, many of the colleagues I worked with are researchers and (potential or actual) ethnographic monitors on whose shoulders the challenges fall and to whom credit is due for the many accomplishments to date.

My ethnographic toolkit comprises chiefly skills and practice in systematic participant observation, interview, and document collection; in the means of recording these through fieldnotes, audio-recording, and photography; and in analyzing and writing up findings in narrative accounts and reports back to my hosts/collaborators, including 
joint authoring with participants. Many years of practice in multilingual learning contexts have given me a practiced eye and a fund of stories from other contexts - stories that prove welcome as participants encounter formidable challenges or recount their experiences in the present context.

The other two pieces of my Hymesian ethnographic toolkit are the "concrete, yet comparative, cumulative, yet critical" approach to ethnographic study of language use (Hymes 1996: 63; see also McCarty et al. 2011) and the emic-etic dialectic principle, i.e. the constant interplay between etic and emic in which (etic) theoretical frameworks are employed to describe and discover local (emic) systems of meaning, and such discoveries in turn change the (etic) frameworks (Hymes 1990: 421, drawing on Pike 1954). For these I draw also on my conceptual repertoire and my knowledge of the South African context, which I describe briefly in the next paragraphs.

My conceptual repertoire comprises a set of frames and metaphors emerging from my own ethnographic research and from theoretical and empirical work by others. This repertoire includes the continua of biliteracy heuristic for educational policy, research, and practice in multilingual settings that attempts to account for the complexity and fluidity of language and literacy learning (Hornberger 1989, 2003, 2010b; Hornberger and Link 2012). The continua framework is complemented and explicated by analytical concepts describing "language-in-motion" in an increasingly mobile world (Blommaert 2010: 5); communicative repertoires made up of the languages, dialects, styles, registers, discourses, and modes individuals and communities draw on in their day-to-day communication (Gumperz 1964; Hymes 1980; Blommaert 2010; Rymes 2010); local and transnational knowledges, literacies and identities that are increasingly a part of global 
human experience (Moll and Gonzalez 1994; Warriner 2007); and flexible bilingual, translanguaging practices in both pedagogical and everyday spaces (Blackledge and Creese 2010; García 2009). The metaphor of language policy and planning (LPP) as a layered onion conceptualizes LPP as not just macro-level policy declarations but as scaled, processual, and dynamic decision-making by states, institutions, and classroom teachers, among others, best understood through the ethnography of language policy (Hornberger and Johnson 2007; Menken and García 2010; Ricento and Hornberger 1996). My ethnographic monitoring of multilingual language policy implementation is also informed by an ecological perspective acknowledging the role of evolution, environment, and endangerment in the life of languages; and an understanding of the importance/dialectic of opening up implementational and ideological spaces in educational policy and practice for fluid, multilingual, oral, and contextualized practices and voices (Hornberger 2002, 2005, 2006; Hornberger and Hult 2008; Menken and García 2010; Schissel 2012).

Finally, my knowledge of the South African context comes from a long-term involvement beginning in 1992, my most sustained involvement in an international context other than the Andes and Latin America, but with two significant limitations - all of my sojourns have been short-term and all of my interactions have been through the medium of English, since I have no proficiency in an African language. It is all the more important in my work, then, to recognize and publish the academic voices and expertise of local and Indigenous researchers and policymakers, a subject to which I will return in the conclusion. 
12 Nancy H. Hornberger

We turn now to the cases, taking up first my 2008 sojourn at the University of Limpopo in Polokwane, and then my 2010 visit to the University of KwaZulu-Natal in Durban. My aim is to contribute to the cumulative and comparative ethnographic study of language use through considering these different contexts and the different tasks I undertook there, using the frame of ethnographic monitoring. My hope is to thereby shed light on the reach of ethnographic monitoring in advancing language education policy, and South Africa's multilingual language policy in advancing Black African learners' academic opportunities. I conclude with some reflections on not taking language inequality for granted.

\section{University of Limpopo, Contemporary English and Multilingual Studies}

I spent several weeks in 2008 at the University of Limpopo at a three-year undergraduate program taught through the medium of both English and seSotho sa Leboa (Northern seSotho), commonly referred to by the name of its major variety, Sepedi. SeSotho sa Leboa is one of South Africa's nine officially recognized African languages and the highly innovative program in Contemporary English and Multilingual Studies (CEMS) is to date South Africa's only bilingual university-level program in English and an African language, founded in 2003 in direct and creative response to the openings afforded by South Africa's multilingual language policy (Granville et al. 1998; Joseph and Ramani 2004, 2006, 2012).

Fieldnotes from one class meeting provide an ethnographic glimpse into the context and emergent findings discussed further below: 
Toward the end of today's Language and Thought class, professor Michael and I step outside to warm ourselves in the sun while students confer among themselves, freely codeswitching in Sepedi and English, as to which of six child language development paradigms best corresponds to a short text describing a child-caretaker interaction. Earlier class activities, in preparation for students' third-year Vygotskyan-inpsired research projects exploring Sepedi-speaking children's private speech, included writing silently about and discussing our own uses of private speech and gauging various data sources (diaries, interviews, questionnaires) along a Likert scale of soft to hard data.

As we step outside, we are approached by one of the first CEMS graduates, Mapelo Tlowane, who greets her professor warmly and reports her language consulting business is picking up and she's had two job interviews. She exudes a contagious enthusiasm and confidence that visibly light up the faces of the current students, who return to their academic task with renewed energy and focus after her brief visit. (Limpopo, 5 August 2008).

CEMS is entirely the creation of its founding directors Esther Ramani and Michael Joseph, and is dependent on their vision and energy. It is, by their own account and my observation, an ongoing struggle to build and sustain CEMS in the University of Limpopo context, both in terms of political support and institutional resources. Even as CEMS celebrated its tenth anniversary in October 2012, and despite its many successes and advances, threats to its survival continued (E. Ramani, personal communication, 29 September 2012). The University of Limpopo, an under-resourced Historically Black College serving a mainly Black African student population, seeks to position itself in the post-apartheid era as an English-medium, international institution offering a wide and increasing range of majors.

Among the challenges met and surmounted is the creation of the Sepedi-medium modules; these were developed and taught along with University of Limpopo graduate Mamphago Modiba (Ramani et al. 2007). Modiba went on to finish her Ph.D. and now holds a permanent position at the university; since 2010, CEMS alumna Mapelo Tlowana (who appears in the vignette) teaches the Sepedi-medium modules. Another set of challenges are logistical ones around space, collegial support, and funding. Fortuitously, 
or perhaps as a strategic precursor to CEMS, Esther and Michael had initiated a Book Club in their early years at Limpopo for students transitioning into university studies, for which they secured a designated classroom space to house the books they donated and collected (Joseph and Ramani 2002). This physical and intellectual space has proven invaluable for CEMS classes and seminars, especially important since their own office space has been severely cramped, with Esther and Michael sharing one small office in which to house not only their own work but also teaching materials, research literature and equipment for the program.

Perhaps their biggest challenge has been in designing and implementing a curriculum to support the development of their students' academic biliteracy (Joseph and Ramani 2004, 2012). In developing the program, they sought to apply research literature including Cummins' four-quadrant model (Cummins 1982) and my continua of biliteracy (Hornberger 1989, 2003). It was this that led them to invite me as Fulbright Senior Specialist to consult with them. We jointly outlined my task along the following lines: first, to document the program by sitting in on classes and interviewing undergraduate and postgraduate students and alumni; second, to meet with the department head, school dean, and university vice-chancellor to get their views on CEMS and its unique contributions; third, to contribute to a developing CEMS research culture by offering university-wide lectures and program seminars on my research on multilingual education — in particular, the continua of biliteracy — and advise postgraduate students on their theses; fourth, to review and revise with CEMS faculty the content, methodology, and assessment procedures in their existing curricular modules; fifth, to develop with CEMS faculty a proposed one-year Honors degree and a two-year Master's degree; and finally, 
to strategize with CEMS faculty on ways to extend the program to include other major languages of the province - xiTsonga and tshiVenda — along with Sepedi.

\subsection{Ethnographic monitoring at Limpopo}

As I worked with Ramani, Joseph, and CEMS students and alumni to document, analyze, and evaluate the current communicative conduct, emergent patterns and meanings, and social outcomes and meanings of the program and policy,, here briefly is what emerged as seen through the ethnographic monitoring frame.

\subsubsection{Documenting communicative conduct}

As suggested in the opening fieldnote vignette, I regularly observed that students make frequent, flexible, and fluid use of Sepedi in their English-medium classes (and vice versa). The communicative repertoire available in the program also includes not only South African English, Afrikaans, and local varieties of Sepedi, but also other local South African languages, as well as foreign languages accessible through the internet and varieties of Indian English and other Indian languages spoken by Ramani and Joseph, who had transplanted themselves from their native India to South Africa in the early 1990s. Seen through the lens of biliteracy media, CEMS learners and teachers are making simultaneous use of structures and scripts ranging along continua from similar to dissimilar and convergent to divergent, as well as of a rich repertoire of styles, registers, modes, and modalities, all comprising what Hymes referred to as instrumentalities of communication (Hymes 1974). Importantly, the flow and fluidity of languages in the classroom reflect and expand on local multilingual communicative practices, oral, written, and electronic. 


\subsubsection{Analyzing emergent patterns and meanings}

The program instantiates the continua of biliteracy in ways that enable significant learning advantages to accrue to the Sepedi-speaking students enrolled. One of the keys to this turned out to be the program's simultaneous emphasis on rigorous academic literacies development in both languages, as repeatedly emphasized by the founders in my conversations with them and as observed, for example, in the third year students' individual research projects on Vygotsky's private speech, mentioned in the opening vignette (see Joseph and Ramani 2012).

The New South Africa's multilingual language policy had the effect of opening up ideological and implementational spaces for the use of marginalized African languages (Hornberger 2002), and CEMS classroom practices quite intentionally exploit these spaces to encourage fluid and flexible use of African languages as media of instruction alongside English; equally, however, they draw on both academic and identity resources for texts, materials, and curriculum, and foster critical awareness and acceptance of students' communicative repertoires, identities, and imagined communities (Kanno and Norton 2003). There can be no question that these emphases and the presuppositions underlying them contribute to the successful student outcomes observed.

\subsubsection{Evaluating the program and policy}

As of 2008, three CEMS cohorts had completed the program and three more were in progress. Of the fourteen students who had completed, seven were pursuing post-graduate studies, two had started a language-consulting firm together, others were working in language-related positions, and two were working in in non-related fields. As Hymes suggests, though, a more telling account of the circumstances and characteristics of a 
program's educational success and political consequences comes from an ethnographic perspective, in this case from interviews with alumni, a sample of which I include here:

Theo finished the BA CEMS degree last year and is teaching English for business communication at a private college. He started the job in February, mid-semester, and was able to bring his students up to a passing mark. He attributes his teaching success to the good training he got at CEMS; for business communication, the analysis of genre, etc. Also, he uses Sepedi in class and encourages his students, ages $16-25$, to do the same; this is so that they can get at a truer understanding of content, even though their writing is ultimately in English. Theo has applied for a job as communications officer in the Department of Labor and is hoping for a job with benefits. Ideally, he would like to work for a few years and then come back for an honors BA and MA in CEMS. (Interview, 15 Aug 2008)

These insights from ethnographic monitoring of the CEMS program, conveyed as they emerged during my visit and written up in reports and subsequent papers in consultation and collaboration with Joseph and Ramani (Hornberger 2010a, 2010b; Joseph and Ramani 2012), helped to inform the ongoing development, expansion, and recognition of the program while I was there and subsequently. Our collaborative ethnographic monitoring also contributed to CEMS' gaining approval for the new proposed Honors program (E. Ramani, personal communication, 21 September 2010) and to growing appreciation for CEMS within the University, South Africa, and internationally (Joseph and Ramani, personal communications). Turning now to my ethnographic monitoring experience at UKZN, we shift scales from program to university level.

\section{University of KwaZulu-Natal, University Teaching and Learning Office}

I spent two weeks in 2010 at the University of KwaZulu-Natal (UKZN) at the invitation of the University Teaching and Learning Office (UTLO), which had recently assumed responsibility for implementing the university's 2006 multilingual language policy. The 
UKZN Language Policy affirms respect for all of South Africa's official, heritage, and other languages, and a commitment to promoting awareness of multilingualism and institutional status for the official languages of KwaZulu-Natal — isiZulu, English, and Afrikaans. Elevation of the status and use of isiZulu in higher education is a major aim, in recognition that 80 percent of KwaZulu-Natal's population speaks isiZulu

Since the UTLO has a university-wide charge, I observed and spoke with faculty and students in schools and departments across the university's five campuses, including the centrally important School of isiZulu Studies, from which this fieldnote excerpt comes:

I am spending a few days with Associate Professor Nobuhle Hlongwa, former isiZulu Studies Head and current Deputy Dean of Humanities, who has been integral to UKZN efforts to implement isiZulu as a medium of instruction, in her roles not only as administrator, but also as isiZulu language teacher, teacher educator, researcher, and research collaborator in a cross-school project funded by SANTED, the South Africa-Norway Tertiary Education Development Program. With a growing number of publications and responsibilites, Nobuhle's national and international career is taking off and she is a key figure in multilingual language policy at UKZN and in South Africa. She invites me and her colleagues to join her graduate language planning seminar where a lively discussion ensues among about 15-20 faculty and master's students, touching on a wide range of issues facing the use of isiZulu in education including the stigma these master's students experience for doing a degree in isiZulu. (Durban, 2 August and 5 August 2010)

The fieldnote vignette provides an ethnographic glimpse into the context and emergent findings discussed in the following paragraphs. In 2010, the University of KwaZulu-Natal (UKZN) was at a critical juncture in its implementation of South Africa's multilingual language policy. Beginning in 2006, UKZN Faculty had approved a Language Policy, Plan, and Budget, outlining steps for implementation in two ten-year phases beginning 2008, and placing responsibility for implementing the Policy in the Faculties, with advice and support from a University Languages Board, Language Planning Facilitator, and language support personnel on each campus charged with 
facilitating isiZulu language development, translation, and isiZulu-medium provision. After some false starts in 2006 and thereafter, the Deputy Vice Chancellor (DVC) for Teaching and Learning, Renuka Vithal, assumed responsibility as of 2010 (see Kamwendo et al. 2013 for an updated overview of the implementation of UKZN's language policy).

At the time of my visit, a University Languages Board chaired by the DVC, a Director of Language Development, and a Language Planning Coordinator located in the UTLO were all expected to be in place before the end of 2010. Part of the purpose of my visit was to facilitate consultation and dialogue across the schools and faculties toward advising the incoming Language Planning Board, Director, and Coordinator on next steps for implementation of the language policy to make UKZN more multilingual in teaching, learning, and research. My specific tasks were, firstly, to observe and to engage in dialogue with faculty, administrators, and postgraduate students of different faculties across different campuses, as well as at public schools and with the English Language Education Trust NGO (see Dhunpath 2010); secondly, to jointly assess current implementation; and thirdly, to jointly identify next steps and strategies.

In some ways, this visit felt less ethnographic than my stay at Limpopo, due to a more explicit and top-down agenda-setting by my hosts, the larger network of programs and people I was responsible for understanding, and the higher proportion of scheduled group meetings to self-initiated participant observation and interviewing. Ethnographic monitoring fits perhaps less obviously here, but I ultimately concluded that it provides a frame for understanding and interpreting my language-policy consulting role in this case too. On the one hand, I pursued my task with the same methodological toolkit, conceptual 
repertoire, and contextual knowledge as in the Limpopo case and on the other, part of the success of my involvement, as I gleaned it from my hosts, was my (ethnographic) ability to listen attentively to all parties and to facilitate, analyze, and synthesize conversations within and across the different faculties that rarely had opportunity to engage in dialogue and information-sharing around these issues. The scale was different, but the monitoring activities were similar.

\subsection{Ethnographic monitoring at UKZN}

Working collaboratively across the university with administrative staff, faculty, and postgraduate students in different departments and schools, the three ethnographic monitoring purposes were foregrounded somewhat differently in each. Yet the overall account that emerges sheds light on the communicative conduct, emergent patterns and meanings, and program and policy outcomes in play at UKZN as a whole.

\subsubsection{Documenting communicative conduct}

Existing and forthcoming pedagogy and curriculum enabling multilingual language use in classes, as gleaned from participant observation, interview and document review, included a class on language planning taught through isiZulu-medium, using Nobuhle's recently published textbook Ukuhlelwa Kolimi (Ndimande-Hlongwa 2009); Language and Literacy Education faculty engaged in curricular planning to design a new track of six modules in applied linguistics and sociolinguistics to accompany six existing modules in literature, some of the new modules to be taught through the medium of isiZulu; plans by the head of the School of Language, Literature and Linguistics to reinitiate applied linguistics programs and modules based on those taught in the past at University of Natal, 
incorporating also her experience and existing research on flexible use of English and isiZulu in classroom instruction (Wildsmith-Cromarty 2008); the three-year SANTED project involving faculty from Nursing, Education, Psychology, and isiZulu Studies in the development of discipline-specific modules in isiZulu, terminology development, and translation activities (Wildsmith and Ndimande-Hlongwa 2010; also Engelbrecht and Wildsmith-Cromarty 2010; Engelbrecht et al. 2008; Ndimande-Hlongwa et al. 2010a, 2010b).

\subsubsection{Analyzing emergent patterns and meanings}

Ecological tensions abounded around opening ideological spaces and shifting educational discourse toward welcoming and accommodating instruction through the medium of isiZulu and other African languages. In local school visits, I observed a first-grade lesson on animals skilfully taught through the medium of English with code-switching to isiZulu to clarify meanings and encourage participation; and met with a group of principals of formerly Indian schools, concerned about what they called the gap in Black students' language from "spoken isiZulu at home to written English at school." In the language planning seminar depicted in the introductory vignette, the master's students, who were all also teachers, talked about school learners writing Zulu-ized English words rather than pure isiZulu in their isiZulu-medium classes, the reaction of parents to new school policies of teaching isiZulu-medium rather than English in the primary grades, and the need for mother-tongue-based multilingual education in the schools and at UKZN to counter the hegemony of English - not to replace English with isiZulu, but in an additive model. Indeed, in conversations with schoolteachers and university faculty the seemingly irreconcilable tension between parents' demand for English as the language of power and 
students' biliteracy development needs surfaced repeatedly; as did the challenges of negotiating multilingualism in classroom and curriculum (see Hornberger 2002); and the perennial "problems in the socio-educational legitimization of vernacular languages" (Fishman 1982: 4) including lack of teachers, materials, or language corpus (grammar, vocabulary, orthography).

Ecological tensions specific to the UKZN context revolved around concerns about the special role of isiZulu and the School of isiZulu Studies in implementing the multilingual language policy. There were concerns lest isiZulu become the sole rather than primary focus of UKZN language policy: What about other South African official, marginalized, and heritage languages? What about languages spoken by immigrants or foreign students, such as French, Portuguese or Kiswahili? And there were concerns as to the appropriate role for the School of isiZulu Studies in the implementation of isiZulumedium teaching across the university; isiZulu faculty expertise is clearly central to the undertaking, but they are neither enough in number nor do they necessarily cover all the areas of expertise required to meet the need.

\subsubsection{Evaluating the program and policy}

What I heard and helped to formulate collaboratively with participants were strategies for moving forward in the implementation of the policy, that is, opening implementational spaces; and calls for disseminating and developing research on the policy. In a sense, what was being called for was more ethnographic monitoring to be undertaken by participants, suggesting an ethnographic monitoring cycle that I as collaborative consultant could highlight and advocate for — and did. 
Strategies for implementation, generated in dialogue with school-specific faculty, staff, and students, took up the following topics. Curricular planning about which modules will be offered through isiZulu medium should yield a repertoire of approaches suited to discipline-specific curricular needs, strengths, and aims as determined by the responsible faculty. An ecological approach would suggest that not every module be offered in both English medium and isiZulu medium, but that some might be, while others might be offered only in English or only in isiZulu, or perhaps in a mixed or hybrid mode with lectures in English and follow-up discussion sections in isiZulu and perhaps other African languages.

Multilingual classroom practices can be explicitly explored and planned for, recognizing that code-switching, recently theorized also as flexible multilingualism (Blackledge \& Creese 2010), bilingual supportive scaffolding (Saxena 2010), and translanguaging (Baker 2003; Blackledge et al. this volume; García 2009; Hornberger and Link 2012), offers a communicative resource to be exploited rather than eschewed. Communicative repertoires for learning and teaching include not only the complexities and fluidities of South Africans' language proficiencies and language varieties and the spoken and written, global, local, and mixed varieties of English, isiZulu, and other languages, but also other representational resources such as visual, gestural, performative, digital, photographic, and so forth (Rymes 2010; Stein 2008).

Academic literacies are to be supported not only in English, but also in isiZulu and possibly other languages, building on several decades of research showing that second language literacies are best built on the foundation of first language literacies (Hornberger 2003; Joseph and Ramani 2012). Assessment practices must be consistent 
with curricular and classroom practices — including formative, portfolio, and especially multilingual assessments, yet to be designed (Mathew 2008).

Language acquisition opportunity and incentive, i.e. "acquisition planning" (Cooper 1989) for isiZulu should be made available for staff and students, including online courses. IsiZulu corpus planning requires a coordinated effort. IsiZulu Studies could set up an electronic clearinghouse for isiZulu terminology development, including dissemination via mass media, and elicitation of feedback from the public.

Calls for disseminating and developing research focused on the following: first, a sociolinguistic survey of primary/secondary education medium of instruction in KwaZulu-Natal that would shed light on such basic (and missing) information as to what proportion of isiZulu-speaking students are taught through isiZulu vs. English medium of instruction and up to what grade; second, ethnographic research on teaching and learning multilingually, that is, language use, code-switching, discourses, and ways of speaking, to be carried out in primary-secondary education classrooms, in community-based clinical practice settings, and in higher education disciplines; third, ethnographic research on first and second language acquisition in Zulu in community and classroom; fourth, corpus planning, for example, terminology development involving students and staff and using an interactive website for dissemination and feedback to build a database; and, last but not least, isiZulu linguistic structure, given the ongoing need for documentation on actual isiZulu language structure and use.

As at Limpopo, the insights gleaned and shared collaboratively with my hosts orally and in writing informed the ongoing development and expansion of their initiatives in multilingual language policy implementation at the higher education level. An update a 
year after my visit revealed a number of our recommended initiatives under way, including a functioning Language Board and Language Office, budget allocations for ten specific curricular projects proposed from the different faculties, and the development of an institution-wide Terminology Development Platform (R. Dhunpath, personal communication, 14 November 2011). Our collaborative conversations, meetings, reports,

and, we hope, future published papers constitute both documentation and interpretation of what has been accomplished and a spur to widen and deepen the effort.

\section{Conclusions}

Returning to our opening questions as to the reach of ethnographic monitoring and of South Africa's multilingual language policy, the faculty/student groups I have worked with in these two contexts remain convinced, like me, that multilingual education alternatives that take and build on Black African learners' home languages in additive rather than subtractive ways offer the best avenues for their academic learning and socioeconomic mobility in post-apartheid South Africa. They remain equally convinced that only through constant and documented persistence will those alternatives be implemented and made to stick. Ethnographic monitoring, whether by invited international consultants, local and Indigenous experts, or both, offers a means to this end. I am not suggesting it is a task achieved simply nor once and for all, and certainly not in one or even several short-term visits by an invited consultant; it requires long-term and local commitment, ingenuity, and courage, such as that embodied in the work I have been privileged to know in Limpopo and KwaZulu-Natal. 
Hymes often reminded applied and educational linguists that despite the potential equality of all languages, differences in language and language use too often become a basis for social discrimination and actual inequality. While we as scholars may take these insights for granted after decades of scholarship, we nevertheless have our work cut out in raising critical language awareness in education and society more broadly. "We must never take for granted that what we take for granted is known to others" (Hymes 1992: 3).

What is obvious for us, and for my hosts and collaborators in Limpopo and UKZN faced with ongoing struggles to enact truly multilingual teaching, learning, and research, is not necessarily so for the colleagues, students, and families we work with in our educational programs, nor for policymakers and popular commentators in the larger society. So long as schools and educational institutions at whatever level continue to define some people as inferior on the "seemingly neutral ground of language" (Hymes 1980: 110), the task for educational and applied linguists must be to seek ways to counter that reality in favor of more socially just education. Based on my experiences in these two South African higher education contexts, I am suggesting here, with Hymes, that ethnographic monitoring in language education policy offers one means toward not taking language inequality for granted.

\section{Acknowledgments}

I thank Esther Ramani, Michael Joseph, and the Fulbright Senior Specialist program for my 2008 stay at University of Limpopo; and Renuka Vithal, Rubby Dhunpath, Michael Samuel, Emmanuel Mgqwashu, Nobuhle Hlongwa, Charlotte Engelbrecht, 
Rosemary Wildsmith-Cromarty, Mervin Ogle, Krish Govender, and the UTLO at University of KwaZulu-Natal for my 2010 visit.

\section{References}

van der Aa, Jef \& Jan Blommaert. 2011. Ethnographic monitoring: Hymes's unfinished business in educational research. Anthropology and Education Quarterly 42(4). 319-334.

Alexander, Neville. 2000. English unassailable but unattainable: The dilemma of language policy in South African education. PRAESA Occasional Papers 3. 27.

Baker, Colin. 2003. Biliteracy and transliteracy in Wales: Language planning and the Welsh National Curriculum. In Nancy H. Hornberger (ed.), Continua of biliteracy: An ecological framework for educational policy, research, and practice in multilingual settings, 71-90. Clevedon: Multilingual Matters.

Banda, Felix. 2000. The dilemma of the mother tongue: Prospects for bilingual education in South Africa. Language, Culture and Curriculum 13(1). 51-66.

Blackledge, Adrian, \& Angela Creese. 2010. Multilingualism: A critical perspective. London: Continuum.

Bloch, Carole \& Neville Alexander. 2003. A luta continua!: The relevance of the continua of biliteracy to South African multilingual schools. In Nancy H. Hornberger (ed.), Continua of biliteracy: An ecological framework for educational policy, research, and practice in multilingual settings, 91-121. Clevedon: Multilingual Matters.

Blommaert, Jan. 2009. Ethnography and democracy: Hymes's political theory of language. Text \& Talk: An Interdisciplinary Journal of Language, Discourse \& Communication Studies 29(3). 257-276.

Blommaert, Jan. 2010. The sociolinguistics of globalization. New York: Cambridge University Press.

Chick, J. Keith. 2003. Constructing a multicultural national identity: South African classrooms as sites of struggle between competing discourses. Journal of Multilingual and Multicultural Development 23(6). 462-478.

Cooper, Robert. L. 1989. Language planning and social change. Cambridge: Cambridge University Press.

Creese, Angela \& Adrian Blackledge. 2010. Translanguaging in the bilingual classroom: A pedagogy for learning and teaching? Modern Language Journal 94. 103-115.

Cummins, Jim. (1982). Tests, achievement and bilingual students. NCBE Focus 9 (Feb. 1982). 1-7.

Dhunpath, Rubby. 2010. Archaeology of a language development NGO: Excavating organisational identity. Saarbrücken, Germany: Lambert Academic Publishing.

Engelbrecht, Charlotte, Z. Nkosi, D. Wentzel, S. Govender \& P. McInerney. 2008. Nursing students' use of language in communicating with isiZulu clients in clinical settings in KwaZulu-Natal. South African Journal of African Languages 28(2). 145-155.

Engelbrecht, Charlotte \& Rosemary Wildsmith-Cromarty. 2010. Exploring multilingualism in a problembased learning setting: Implications for classroom and clinical practice in the nursing discipline. AlterNation 17(1). 108-137.

Fishman, Joshua A. 1982. Sociolinguistic foundations of bilingual education. The Bilingual review/ La revista bilingüe 9(1). 1-35.

García, Ofelia. 2009. Bilingual education in the $21^{\text {st }}$ century: A global perspective. Malden: WileyBlackwell.

Granville, Sheila, Hilary Janks, M. Mphahlele, Yvonne Reed, P. Watson, Michael Joseph \& Esther Ramani. 1998. English with or without $\mathrm{g}(\mathrm{u}) \mathrm{ilt}$ : A position paper on language in education policy for South Africa. Language and Education 12(4). 254-272.

Gumperz, John. J. (1964). Linguistic and social interaction in two communities. American Anthropologist 66(6, part 2). 137-153. 
Haugen, Einar. 1973. The curse of Babel. In Morton Bloomfield \& Einar Haugen (eds.), Language as a human problem, 33-43. New York: W. W. Norton \& Co.

Heugh, Kathleen. 2003. Language Policy and Democracy in South Africa: The Prospects of Equality within Rights-based Policy and Planning. Unpublished Ph.D., Stockholm University, Stockholm, Sweden.

Heugh, Kathleen, Amanda Siegruhn \& Peter Plüddemann (eds.).1995. Multilingual education for South Africa. Johannesburg: Heinemann.

Hornberger, Nancy. H. 1989. Continua of biliteracy. Review of Educational Research 59(3). 271-296.

Hornberger, Nancy H. 2002. Multilingual language policies and the continua of biliteracy: An ecological approach. Language Policy 1(1). 27-51.

Hornberger, Nancy H. (ed.). 2003. Continua of biliteracy: An ecological framework for educational policy, research and practice in multilingual settings. Clevedon: Multilingual Matters.

Hornberger, Nancy H. 2005. Opening and filling up implementational and ideological spaces in heritage language education. Modern Language Journal 89(4). 605-609.

Hornberger, Nancy H. 2006. Nichols to NCLB: Local and global perspectives on U.S. language education policy. In Ofelia García, Tove Skutnabb-Kangas \& María Torres-Guzmán (eds.), Imagining multilingual schools: Languages in education and glocalization, 223-237. Clevedon: Multilingual Matters.

Hornberger, Nancy H. 2010a. Foreword. In Kate Menken \& Ofelia García (eds.), Negotiating language policies in schools: Educators as policymakers, xi-xiii. New York: Routledge.

Hornberger, Nancy H. 2010b. Language and education: A Limpopo lens. In Nancy H. Hornberger \& Sandra L. McKay (eds.), Sociolinguistics and language education, 549-564. Bristol: Multilingual Matters.

Hornberger, Nancy H. \& Francis M. Hult. 2008. Ecological language education policy. In Bernard Spolsky \& Francis M. Hult (eds.), Handbook of educational linguistics, 280-296. Malden: Blackwell Publishers.

Hornberger, Nancy H. \& David Cassels Johnson. 2007. Slicing the onion ethnographically: Layers and spaces in multilingual language education policy and practice. TESOL Quarterly 41(3). 509-532.

Hornberger, Nancy H. \& Holly Link. 2012. Translanguaging and transnational literacies in multilingual classrooms: A biliteracy lens. International Journal of Bilingual Education and Bilingualism 15(3). 261-278.

Hymes, Dell H. 1968. The ethnography of speaking. In Joshua A. Fishman (ed.), Readings in the sociology of language, $99-138$. The Hague: Mouton.

Hymes, Dell H. 1972. On communicative competence. In John B. Pride \& Janet Holmes (eds.), Sociolinguistics: Selected readings, 269-293. Harmondsworth: Penguin Books.

Hymes, Dell H. 1974. Foundations in sociolinguistics: An ethnographic approach. Philadelphia: University of Pennsylvania Press.

Hymes, Dell H. 1980. Language in education: Ethnolinguistic essays. Washington D.C.: Center for Applied Linguistics.

Hymes, Dell H. 1990. Epilogue to 'The things we do with words'. In Donal Carbaugh (ed.), Cultural communication and intercultural contact, 419-429. Hillsdale: Lawrence Erlbaum.

Hymes, Dell H. 1992. Inequality in language: Taking for granted. Penn Working Papers in Educational Linguistics 8(1). 1-30.

Hymes, Dell H. 1996. Report from an underdeveloped country: Toward linguistic competence in the United States. In Ethnography, linguistics, narrative inequality: Toward an understanding of voice, 63-105. Bristol: Taylor \& Francis.

Hymes, Dell H. et al. 1981. Ethnographic monitoring of children's acquisition of reading/language arts skills in and out of the classroom: Final report. Philadelphia: University of Pennsylvania Graduate School of Education.

Joseph, Michael \& Esther Ramani. 2002. Discovering and developing book lovers through a FoundationYear module. In Luanga A. Kasanga \& Teboho J. Lebakeng (eds.), Paradigm shift in South African higher education, 53-63. Polokwane: University of the North Press.

Joseph, Michael \& Esther Ramani 2004.. Academic excellence through language equity: A new bilingual degree (in English and seSotho sa Leboa). In Hanlie Griesel (ed.), Curriculum responsiveness: Case 
studies in higher education, 237-261. Pretoria, South Africa: South African Universities ViceChancellors Association.

Joseph, Michael \& Esther Ramani. 2006. English in the world does not mean English everywhere: The case for multilingualism in the ELT/ESL profession. In Rani Rubdy \& Mario Saraceni (eds.), English in the world: Global rules, global roles, 186-199. London: Continuum.

Joseph, Michael \& Esther Ramani. 2012. 'Glocalization': Going beyond the dichotomy of global vs. local through additive multilingualism. International Multilingual Research Journal 6(1). 22-34.

Kamwangamalu, Nkonko. 1997. Multilingualism and education policy in post-apartheid South Africa. Language Problems and Language Planning 21(3). 234-253.

Kamwendo, Gregory, Nobuhle Hlongwa \& Nhlanhla Mkhize. (2013). On medium of instruction and African scholarship: The case of IsiZulu at the University of KwaZulu-Natal in South Africa. Current Issues in Language Planning 15(1): 75-89.

Kanno, Yasuko \& Bonny Norton (eds.). 2003. Imagined communities and educational possibilities. Journal of Language, Identity, and Education 2(4), entire issue.

Mathew, Rama. 2008. Assessment in multilingual societies. In Elana Shohamy \& Nancy H. Hornberger (eds.), Encyclopedia of language and education: Volume 7: Language testing and assessment, 19-36. New York: Springer.

McCarty, Teresa L., James Collins \& Rodney K. Hopson. 2011. Dell Hymes and the new language policy studies: Update from an underdeveloped country. Anthropology and Education Quarterly 42(4). 335363.

Menken, Kate \& Ofelia García (eds.). 2010. Negotiating language policies in schools: Educators as policymakers. New York: Routledge.

Moll, Luis \& Norma González. 1994. Lessons from research with language-minority children. Journal of Reading Behavior 26(4). 439-456.

Ndimande, Nobuhle. 2004. Language and identity: The case of African languages in South African higher education. AlterNation 11(2). 62-84.

Ndimande-Hlongwa, Nobuhle. 2009. Ukuhlelwa Kolimi ['Language planning']. Pietermaritzburg: Shuter \& Shooter Publishers.

Ndimande-Hlongwa, Nobuhle, Robert Balfour, Nhanhla Mkhize \& Charlotte Engelbrecht. 2010a. Progress and challenges for language policy implementation at the University of KwaZulu-Natal. Language Learning Journal 38(3). 347-358.

Ndimande-Hlongwa, Nobuhle, Gugulethu Mazibuko \& Mary Gordon. 2010b. The teaching and learning of IsiZulu as a second language for professional purposes at the University of KwaZulu-Natal: A response to professional needs. AlterNation 17(1). 138-164.

PANSALB. 2001. Language use and language interaction in South Africa: A national sociolinguistic survey. PANSALB Occasional Papers, 1. 16.

Perry, Timothy. 2004. Language rights, ethnic politics: A critique of the Pan South African Language Board. PRAESA Occasional Papers 12. 223.

Pike, Kenneth. 1954. Emic and etic standpoints for the description of behavior. In Kenneth Pike (ed.), Language in relation to a unified theory of the structure of human behavior, 37-72). The Hague: Mouton.

Plüddemann, Peter R. (2013). Language Policy from Below: Bilingual Education and Heterogeneity in postapartheid South Africa. Unpublished Ph.D. Stockholm University, Stockholm, Sweden.

Probyn, Margaret. 2001. Teachers' voices: Teachers' reflections on learning and teaching through the medium of English as an additional language in South Africa. International Journal of Bilingual Education and Bilingualism 4(4). 249-266.

Ramani, Esther, Tebogo Kekana, Mamphago Modiba \& Michael Joseph. 2007. Terminology development versus concept development: Insights from a dual-medium BA degree. Southern African Linguistics and Applied Language Studies 25(2). 207-233.

Republic of South Africa. 1996. Constitution. http://www.info.gov.za/documents/ constitution/1996/a10896.pdf (accessed).

Ricento, Thomas K. \& Nancy H. Hornberger. 1996. Unpeeling the onion: Language planning and policy and the ELT professional. TESOL Quarterly 30(3). 401-428. 
Ridge, Stanley G. M. 2004. Language planning in a rapidly changing multilingual society: The case of English in South Africa. Language Problems and Language Planning 28(2). 199-215.

Rymes, Betsy. 2010. Classroom discourse analysis: A focus on communicative repertoires. In Nancy H. Hornberger \& Sandra L. McKay (eds.), Sociolinguistics and language education, 528-546. Bristol: Multilingual Matters.

Saxena, Mukul. 2010. Reconceptualising teachers' directive and supportive scaffolding in bilingual classrooms within the neo-Vygotskyan approach Journal of Applied Linguistics \& Professional Practice 7(2). 169-190.

Schissel, Jamie L. 2012. The pedagogical practice of test accommodations with emergent bilinguals: Policy-enforced washback in two urban schools. Unpublished Ph.D. University of Pennsylvania, Philadelphia.

Stein, Pippa. 2008. Multimodal pedagogies in diverse classrooms: Representation, rights, and resources. London \& New York: Routledge.

van der Walt, Christa. 2004. The challenge of multilingualism: In response to the language policy for higher education. South African Journal of Higher Education 18(1). 140-152.

van der Walt, Christa \& C. Brink. 2005. Multilingual universities: A national and international overview. South African Journal of Higher Education 19(4). 822-851.

Warriner, Doris S. 2007. Transnational literacies: Immigration, language learning, and identity. Linguistics and Education 18(3/4), entire.

Webb, Victor. 2002. Language in South Africa: The role of language in national transformation, reconstruction, and development. Amsterdam/Philadelphia: John Benjamins.

Wildsmith-Cromarty, Rosemary. 2008. Can academic/scientific discourse really be translated across English and African languages? Southern African Linguistics and Applied Language Studies 26(1). $147-169$.

Wildsmith-Cromarty, Rosemary. 2009. Multilingualism in South African schools: Where to now? In María E. Torres-Guzmán \& Joel Gómez (eds.), Global perspectives on multilingualism: Unity in diversity, 36-53. New York: Teachers College Press.

Wildsmith, Rosemary \& Nobuhle Ndimande-Hlongwa. 2010. AlterNation17(1). Special edited issue on the SANTED findings. http://alternation.ukzn.ac.za/docs (accessed). 